\title{
HOXA5 Gene
}

National Cancer Institute

\section{Source}

National Cancer Institute. HOXA5 Gene. NCI Thesaurus. Code C132093.

This gene plays a role in the regulation of gene transcription during embryogenesis. 